\title{
Investigation Of Physical Properties Of Poly(Lactic Acid)/Eggshell Powder Composite Films
}

\author{
Savas Gurdal 1* \\ 1* Science and Technology Application and Research Center, Çanakkale Onsekiz Mart University, Çanakkale, Turkey, \\ (ORCID: 0000-0002-1149-4371), savas.gurdal@comu.edu.tr
}

(International Conference on Design, Research and Development (RDCONF) 2021 - 15-18 December 2021)

(DOI: 10.31590/ejosat.1044796)

ATIF/REFERENCE: Gurdal, S., (2021). Investigation of Physical Properties of Poly(Lactic Acid)/Eggshell Powder Composite Films. European Journal of Science and Technology, (32), 398-402.

\begin{abstract}
In this work, the effects of Chicken egg shell powder (ESP) on the properties of Poly(Lactic Acid) PLA/ESP composite films (products) were examined. 4 wt.\% PLA solution prepared and ESP added to solution at wt. \%10, \%20, \%30, \%50. PLA and PLA/ESP films prepared by the film-casting method. The mechanical and thermal behaviours of the composites were investigated using fourier transform infrared spectroscopy (FTIR), xray diffraction analysis (XRD), thermogravimetric analysis (TGA), dynamic mechanic anaylsis (DMA) and polarized optical microscopic analysis. While ESP added in different amounts into the PLA film also increases the crystal density the composite film as the amount of substance increases. Also, as the amount of ESP in the product increased, the thermal stability of the composite films increases and a sharper and roughness structure is occurs. $\% 10$ and $\% 20$ ESP added composites had elasticity properties as PLA, while high-strength composite film formation was observed at $\% 30$ and $\% 50$ ESP added composites. So, the storage modulus is seen at a higher level than normal PLA. These composites could be used in packaging application because of reducing light permeability properties and high-strength composite film formation.
\end{abstract}

Keywords: Eggshell Powder, Poly(Lactic Acid)(PLA), Composite films

\section{Poli(Laktik Asit)/Yumurta Kabuğu Tozu Kompozit Filmlerin Fiziksel Özelliklerinin İncelenmesi}

$\ddot{O} \mathbf{z}$

Bu çalı̧̧mada, yumurta kabuğu tozu'nun (YKT) Poli(Laktik Asit)(PLA)/YKT kompozit filmlerinin özelliklerine etkileri incelenmiştir. Bu kapsamda ağırlıkça \%4 PLA çözeltisi hazırlanmış ve bu çözeltiye ağılıkça \%10, \%20, \%30, \%50 oranlarında YKT eklenmiştir. PLA ve PLA/YKT kompozit filmleri, film döküm yöntemiyle hazırlanmıştır. Kompozitlerin mekanik ve termal davranışları, fourier dönüşüm kızılötesi spektroskopisi (FTIR), x ışını kırınım analizi (XRD), termogravimetrik analiz (TGA), dinamik mekanik analiz (DMA) ve polarize optik mikroskobik analiz kullanılarak incelenmiştir. PLA filme eklenen YKT miktarı arttıkça, kompozit filmin kristal yoğunluğunu arttığı gözlemlenmiştir. Benzer şekilde, saf PLA filme göre PLA-ESP kompozitinin termal kararlılığı da artan madde miktarı ile beraber artmış, daha koyu ve pürüzlü yapılar oluşmuştur. \% 10 ve \%20 YKT katkılı kompozitler PLA'ya benzer elastik özelliklere sahipken, \% 30 ve \%50 YKT katkılı kompozitlerde yüksek mukavemetli kompozit film oluşumu gözlenmiş̧ir. Bundan dolayı da depolama modülü normal PLA'dan daha yüksek bir seviyede görülmüştür. Bu kompozitler sahip oldukları yüksek mukavemet ve düşük ışık geçirgenlik özellikleri sayesinde bazı özel film uygulamalarında kullanılabilir.

Anahtar Kelimeler: Yumurta kabuğu tozu, Poli(Laktik Asit), Kompozit filmler 


\section{Introduction}

In recent years, due to environmental concerns and sustainability problems associated with petrochemical-based polymers, there has been an increasing trend towards scientific research and engineering studies for the modification of biodegradable and renewable polymers. Developing new packaging materials with both sustainability and adequate functional properties are necessary in todays. So, new polymer matrices and bio-based materials have been started to be developed using additives obtained from completely renewable resources (Arrieta, Peltzer, Lopez, Garrigos, Valente, \& Jimenez, 2014). Materials produced from renewable resources, especially poly(lactic acid) and starch, are attracting more attention day by day, which have biodegradation capabilities (Lim, Auras, \& Rubino, 2008).

Aliphatic polyesters are known as biodegradable, good performance and environmentally friendly polymer materials. Pla is a linear aliphatic polyester and its mechanical properties such as Young's modulus and tensile strength are similar to polyethylene terephthalate (PET) and nylon. Because of these similar properties, it can be used as a substitute for petroleumbased polymers ( Rahman, Santis, Spagnoli, Ramorino, Penco, Phuong \& Lazzeri, 2013). PLA attracts attention in the industry due to its biodegradable and compostable properties (Fortunati, Armentano, Zhou, Iannoni, Saino, Visai, Berglund \& Kenny, 2012). In addition to being used in the production of extruded film and injection-coated fiber, especially in recent years, its practical applications are limited due to its low thermal stability and natural fragility. Last decades Pla is used in the production of extruded film and injection-coated fiber however its practical applications are limited due to its low thermal stability and natural fragility. To overcome these limitations Pla is hardened with plasticizers or polymers ( Armentano, Fortunati, Burgos, Dominici, Luzi \& Fiori, 2015; Arrieta\&Samper, et al., 2014). In addition, PLA is called green material in packaging as an alternative to polymers. Potential packaging studies of PLA is limitless. Therefore, with PLA's oxygen permeability feature, it is ideal to preserve the freshness of foods ( Juan, Zhao, Zhao \& Xi, 2012). The most important feature when choosing a polymer is the crystallinity level of the polymer. Because the level of crystallinity affects (Kowalewska \&Nowacka, 2020).

In countries where the egg industry is developed, it is known that the egg shell is an industrial by-product that causes the worst environmental problems. Compositing of polymers with low-cost, high-performance fillers with renewable and bio-based hardening properties can be seen as a new environmentally friendly approach (Toro, Quijada, Yazdani-Pedram \& Arias, 2007). In addition, 250,000 tons of eggshells are produced annually, with an approximate cost of 100,000 Euros per year ( Zieleniewska, Leszczyński \& Szczepkowski,2016). Eggshell can be an ideal filling source for polymer materials, as well as being used in many applications due to its chemical composition ( Hassan, Aigbodion, \& Patrick, 2012). Eggshell is a biomaterial that contains $95 \%$ by weight calcium carbonate and organic substances such as $5 \%$. It is a protein matrix covered with crystalline minerals. İt consists calcium carbonate, although it differs according to the type from which its specie ( Shuhadah, Supri \& Kamarddin, 2008).

Many studies have been conducted in which eggshell is used as a filler in polymer composites. Murugan, Munusamy \& Ismail (2017), studied the thermal and mechanical effects of eggshell size on the PVC/ESP composite matrix. It was observed that the particle size did not have an effect on the thermal properties, while the distribution of the particles affected the mechanical properties. The study evaluating the mechanical properties of polyamide-ESP composite materials was carried out by Cahala,Vamsi \& Sreenivasulu (2014). Ashok, Naresh, Reddy, Madhukar, Cai, Zhang \& Rajulu (2014), added $1-5 \%$ by weight ESP to Pla in their study. They examined the physical proporties of composites. As a result of the studies, it was observed that the thermal stability of the composite films increased. Polyester and ESP were prepared in different volumetric compositions. Change in PLA when chicken egg shell powder is added and intumescent flame properties (IFR) of the eggshell composite obtained with plasticized PLA was investigated. It has been seen that ESP can be used as a filler in the IFR system ( Urtekin, Hazer \& Aytac,2021). Poli(lactic acids), rubber (R) and chicken eggshell powder were melted in a twin screw extruder to analysis effects of the natural rubber and modified eggshell on physical properties of the composite. Addition of NR and ESP decreased the glass transition temperature and cold crystallization temperature. It was also observed that PLA changed in crystallinity and crystalline form (Somdee \&Hasook 2017).

The aim of this study is the investigate physical properties of new obtained chicken eggshell powder products. The effects of eggshell powder on the properties of products were examined. The mechanical and thermal behaviours of the composites were investigated using XRD, TGA, FTIR, DMA and Microscopic Analysis.

\section{Material and Method}

\subsection{Materials}

Commercial PLA (Solanyl, Carberry, Manitoba, Canada) as polymer, natureworks pla d40 43 was supplied by Sigma Aldrich. Dichloromethane (DCM, Merck, Darmstad, Germany) was used as solvent. Commercial egg shell powder (ESP) was purchased by Egglin Co. ,Turkey.

\subsection{Methods}

\subsubsection{Prepariton Of Composite Films}

PLA was dissolved in DCM to make 4 wt.\% solution. 0.4 gram PLA dissolves in $10 \mathrm{ml}$ DCM and ESP added to this solution at wt. $\% 10, \% 20, \% 30, \% 50$ and stirred. All products prepared by the film-casting method. PLA/ESP products are shown at figure 1 .

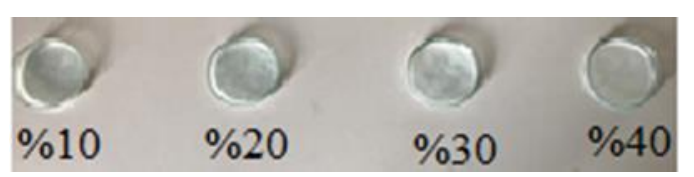

Figure 1. PLA/ESP Composite Films

\subsubsection{X-ray Diffraction Analysis}

XRD analysis was carried out to examine the crystal structure of ESP with $\mathrm{CaCO}_{3}$ crystal structure in the composite formed with PLA. Analyzes were made on XRD device of PANalytical Empyrean brand model. XRD powder diffraction patterns were obtained in the range of $5^{\circ}-70^{\circ} 2$ theta at X-ray tube $\mathrm{Cu} \mathrm{K}$-alpha $1.5645 \mathrm{Kv} 40 \mathrm{~mA}$. Matching of CaCO3 and ESP was done using High Score Plus software. 


\subsubsection{Thermogravimetric Analysis}

In order to determine the thermal effect of ESP on PLAcomposite, measurements were taken in the device of the Perkin ELMER TGA-8000 brand model. Analyzes were carried out 25 ${ }^{\circ} \mathrm{C}$ to $1000{ }^{\circ} \mathrm{C}$.

\subsubsection{FT-IR Spectral Analysis}

Perkin Elmer Spectrum 100 brand model FT-IR spectrometer was measured in the range of $4000-650 \mathrm{~cm}^{-1}$ to determine the functional groups of PLA-ESP Composite films.

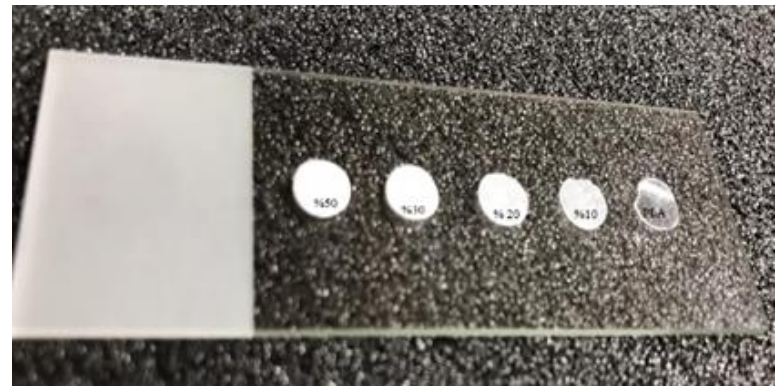

Figure 2. FTIR Analysis Samples of Films

\subsubsection{Dynamic Mechanic Anaylsis}

Perkin elmer DMA 8000 Brand DMA model was used to characterize the mechanical properties of composite films. Analysis was carried out in tensine mode at a heating rate of 3 ${ }^{\circ} \mathrm{C} / \mathrm{min}$ in the temperature range of $-50{ }^{\circ} \mathrm{C}$ to $160{ }^{\circ} \mathrm{C}$. Its frequency is set to $1 \mathrm{HZ}$ and Strain is set to $0.01 \mathrm{~mm}$.

\subsubsection{Microscopic Analysis}

In order to elucidate the surface morphology of PLA / ESP products, photographs were taken with polarized optical microscopy of Nikkon Eclipse e200 brand model. Photographs were taken using a polarized optical microscope with light under illumination and $4 \mathrm{x}$ magnification

\section{Results and Discussion}

The effects of chicken eggshell powder on the properties of PLA and eggshell powder based products were examined. The mechanical and thermal behaviours of the composites were investigated using XRD, TGA, FT-IR Spectral Analysis FTIR, DMA and Microscopic Analysis.

$\mathrm{XRD}$ analysis was carried out to examine the crystal structure of ESP with $\mathrm{CaCO}_{3}$ crystal structure in the composite formed with PLA. X-ray diffraction patterns of products containing PLA and PLA-ESP are given in Figure 3. It is seen that no peak is observed in the X-ray diffraction pattern due to the amorphous structure of the unadulterated PLA film. The peaks of ESP are seen as $\mathrm{CaCO}_{3}$ at $23.32,29.65,39.71,43.43,47.91,48.81$ 2theta degrees. ESP added in different amounts into the PLA film also increases the crystal density in the composite film as the amount of substance increases. Moreover, the flatness disappeared in the range of 1020 degrees 2theta. However, the addition of $\mathrm{CaCO}_{3}$ did not cause PLA to show crystalline properties.

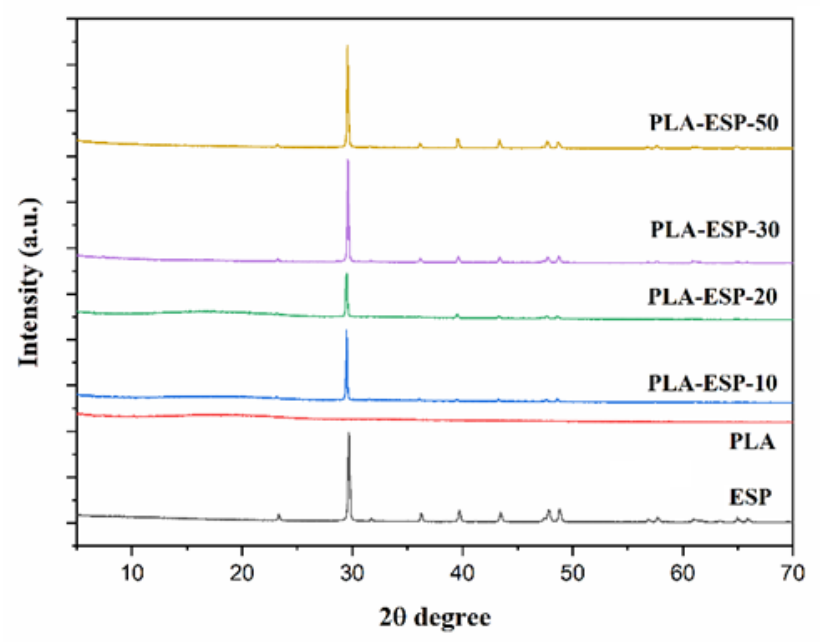

Figure 3. XRD of PLA and PLA/ESP products

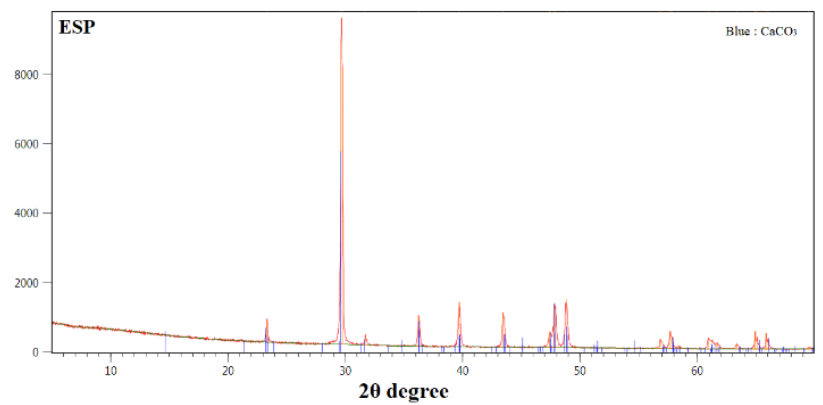

Figure 4. Matching $\mathrm{XRD}$ of $\mathrm{CaCO}_{3}$ and ESP

Thermal gravimetric analysis was performed to determine the thermal effect of ESP on PLA-composite. TGA analysis is shown in fig.5 . As a result of TGA analysis, The thermal stability of PLA-ESP products increases when the amount of eggshell increases. Also, the thermal stability of the compositions is greater than that of the pure PLA film. While the PLA degradation temperature is $348{ }^{\circ} \mathrm{C}$, the decomposition temperatures of the composite PLA-ESP film are $348{ }^{\circ} \mathrm{C}$ and $750{ }^{\circ} \mathrm{C}$. (Valeriya Kudryavtseva, Zhao, Tverdokhlebov\&Sukhorukov, 2017) As the amount of ESP in the composite increased and It has been observed that the thermal stability is higher.

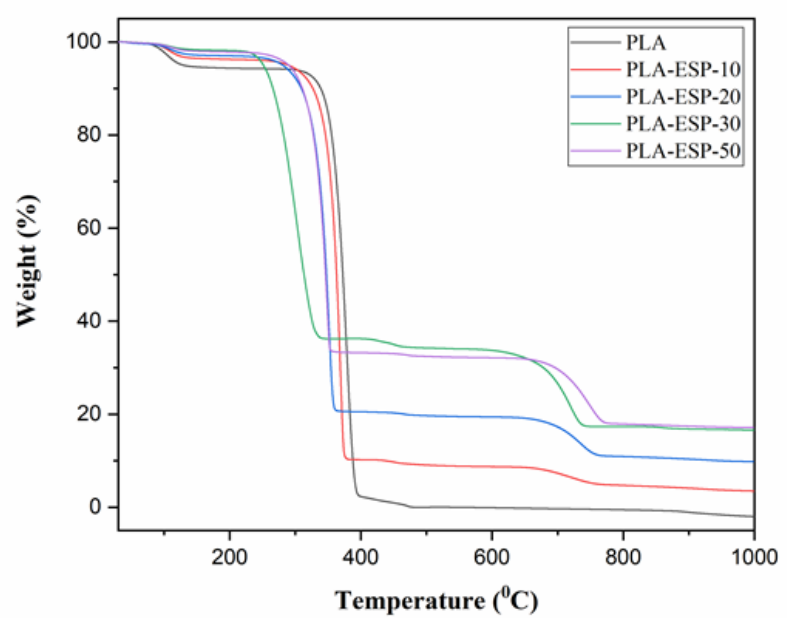

Figure 5. TGA Analysis of Products

FTIR is conducted to determine PLA-ESP products' chemical functional groups . FTIR spectra of PLA-ESP films are 
shown in Figure 6. At $3600 \mathrm{~cm}^{-1}$, there is a $-\mathrm{OH}$ stretching vibration of the $-\mathrm{OH}$ groups at the end of each PLA chain. $\mathrm{CH}_{3}$ asymmetric and symmetric stretching vibrations are observed at 2996, $2946 \mathrm{~cm}^{-1}$. $\mathrm{C}=\mathrm{O}$ in the peak ester groups at $1742 \mathrm{~cm}^{-1}$ is referred to as the stress. At the $1080 \mathrm{~cm}-1$ there was an asymmetrical C-O-C stretching vibration (Bouamer, Benrekaa \&Younes, 2021). ESP and PLA-ESP composites, the absorption bands of carbonate are clearly seen at $873 \mathrm{~cm}^{-1}$ and $1407 \mathrm{~cm}^{-1}$. Based on these data, the presence of $\mathrm{CaCO}_{3}$ in eggshell powder has been proven. Krithiga, Gunasekaran, Sastry \& Thotapalli (2011). The peak regions of ESP overlapped with the peaks of PLA and showed a shielding effect. The increase in the amount of matter of PLA-ESP products decreased the permeability compared to the pure PLA film (Ashok et al.,2014).

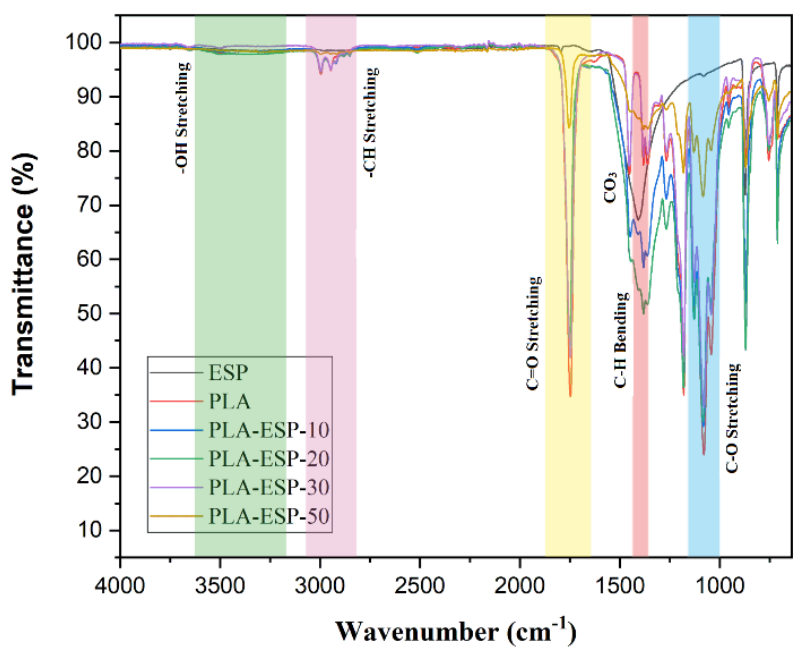

Figure 6. FTIR Spectra of Products

In order to elucidate the surface morphology of Pla / Esp composite films, photographs were taken with polarized optical microscopy. Photographs were taken using a polarized optical microscope with light under illumination and 4x magnification.
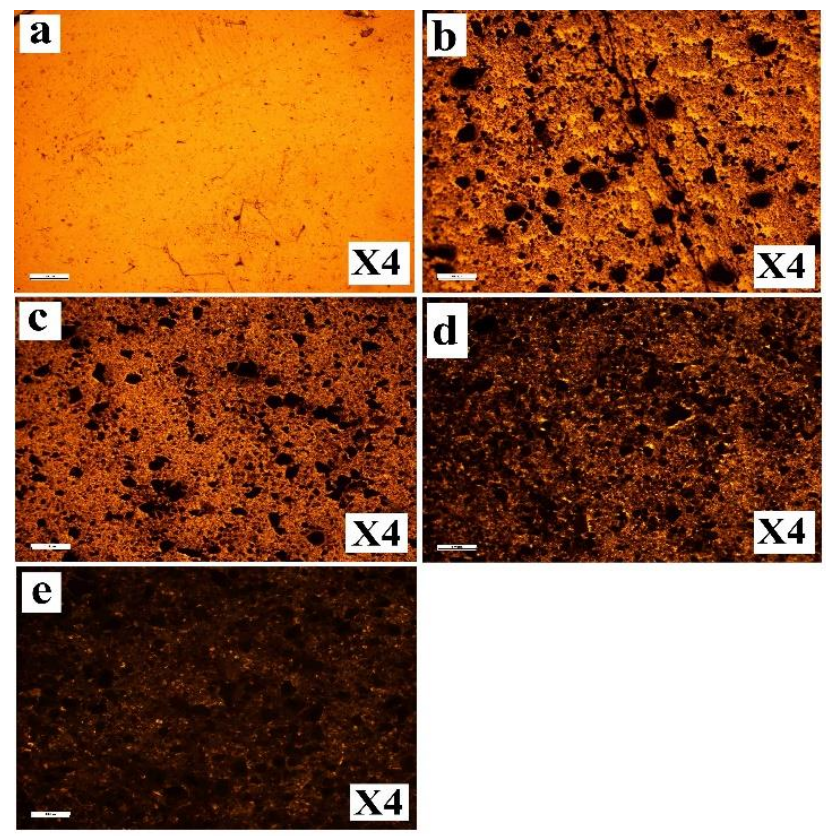

Figure 7. Optical micrographs of Products, (a) PLA (b) 10 wt. $\%$, (c) $20 w t . \%, 30 w t \%$, and (e) $50 w t . \%$.

e-ISSN: 2148-2683
As seen in the figure 7, as the ESP concentration increases, the light transmittance decreases when lighting is made from the bottom. ESP has created a rough and hollow structure. The image in figure7(a) is seen transparent. When ESP is added to PLA, a sharper and roughness structure is occurs.

DMA analysis was performed to characterize the mechanical properties of composite films. Analysis was performed in tensine mode at -50 to $160{ }^{\circ} \mathrm{C}$. Its frequency is set to $1 \mathrm{~Hz}$ and Strain is set to $0.01 \mathrm{~mm} . \% 10$ and \% 20 ESP added composites had elasticity properties as PLA, while high-strength composite film formation was observed at \% 30 and \%50 ESP added composites. So, the storage modulus is seen at a higher level than normal PLA as it seen like Ashok et al. (2014) studies.

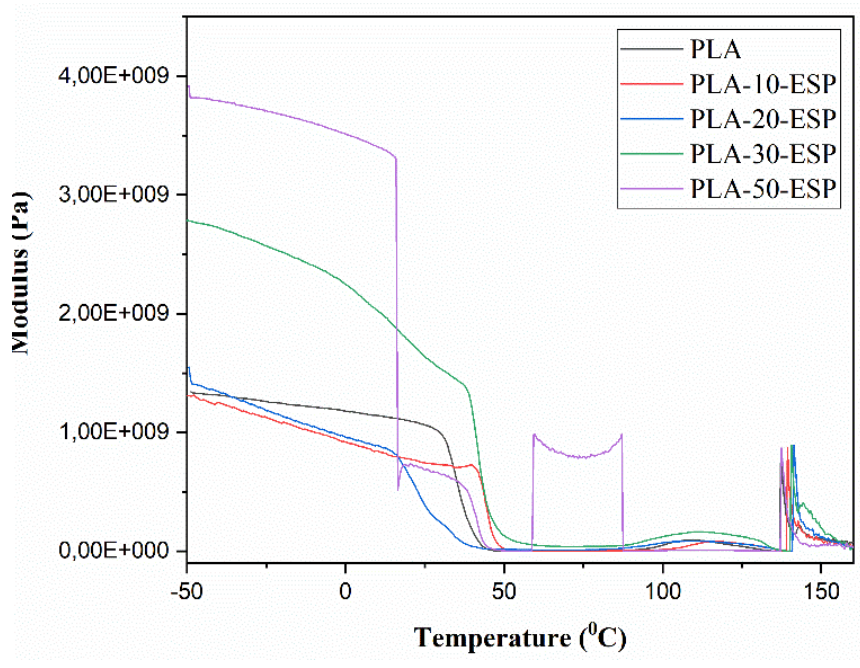

Figure 8. DMA Analysis of Products

\section{Conclusions and Recommendations}

The effects of Eggshell Powder (ESP) on the properties of Poly(Lactic Acid)(PLA) /ESP composites films were examinedin this study. 4 wt.\% PLA solution prepared and chicken egg shell powder added solution at wt. $\% 10, \% 20, \% 30, \% 50$. All products prepared by the film-casting method. Then, XRD, TGA, FTIR, DMA and Polarized Optical Microscopic Analysis were conducted to investigate mechanical and thermal proporties of PLA and PLA/ESP products. ESP added in different amounts into the PLA film also increases the crystal density in the composite film as the amount of substance increases. Moreover, the flatness disappeared in the range of 10-20 degrees 2theta. However, the addition of $\mathrm{CaCO}_{3}$ did not cause PLA to show crystalline properties. The thermal stability of PLA-ESP products increases when the amount of eggshell increases. While the PLA degradation temperature is $348{ }^{\circ} \mathrm{C}$, the decomposition temperatures of the composite PLA-ESP film are $348^{\circ} \mathrm{C}$ and 750 ${ }^{\circ} \mathrm{C}$. The FTIR peak regions of ESP overlapped with the peaks of PLA and showed a shielding effect. When the Optical micrographs are analysised It is clear that ESP concentration increases and the light transmittance decreases with the more ESP. And \% 10 and \% 20 ESP added composites had elasticity properties as PLA, while high-strength composite film formation was observed at \% 30 and \%50 ESP added composites. So, these composites could be used in packaging application because of reducing light permeability properties and high-strength composite film formation. 


\section{Acknowledge}

The author is thankful to Mert AKGUN ( Canakkale Onsekiz Mart Universty, Science and Technology Application and Research Centre ) for his assistance.

\section{References}

Arrieta, M. P., Peltzer, M. A., Lopez, J., Garrigos, M.d. C., Valente, A. J. M., \& Jimenez, A. (2014), Functional properties of sodium and calcium caseinate antimicrobial active films containing carvacrol. Journal of Food Engineering, 121(0), 94-101.

Lim, L. T., R. Auras, and M. Rubino. (2008), Processing technologies for poly(lactic acid). Prog. Polym. Sci. 33(8): 820-852.

Armentano, I., Fortunati, E., Burgos, N., Dominici, F., Luzi, F., Fiori, S., et al (2015), Processing and characterization of plasticized PLA/PHB blends for biodegradable multiphase systems. Express Polymer Letters, 9.

Juan, Zhao, F. Zhao, K. Xi, (2012), Preparation of PLA/nano-ZnO composites, Adv. Mater. Res. 476-478 1901-1904.

A. Kowalewska \& M. Nowacka (2020), Supramolecular Interactions in Hybrid PolylactideBlends-The Structures, Mechanic Properties Molecules. 25 (15) 3351.

Hassan, S. B., V. S. Aigbodion, and S. N. Patrick. (2012), Development of polyester/eggshell particulate composites. Tribol. Ind. 34(4): 217-225.

Toro, P., R. Quijada, M. Yazdani-Pedram, and J. L. Arias. (2007), Eggshell, a new bio-filler for polypropylene composites. Mater. Lett. 61(22): 4347-4350.

Shuhadah, S.Supri, M. Kamarddin, (2008) In: Proceeding of MUCET, UniMAP, Kangar, Perlis, 15-16.

Zieleniewska M, Leszczyński MK, Szczepkowski L, (2016), Development and applicational evaluation of the rigid polyurethane foam composites with egg shell waste. Polym Degrad Stab.;132:78-86.

Murugan S, Munusamy Y, Ismail H.(2017), Effects of chicken eggshell filler size on the processing, mechanical and thermal properties of PVC matrix composite. Plast Rubber Compos. 46(1):42-51.

B. Ashok, S. Naresh, K. Obi Reddy, K. Madhukar, J. Cai, L. Zhang \& A. Varada Rajulu (2014), Tensile and Thermal Properties of Poly(lactic acid)/Eggshell Powder Composite Films, International Journal of Polymer Analysis and Characterization, 19:3, 245-255.

Gizem Urtekin, Seda Hazer \& Ayse Aytac (2021), Effect of eggshell and intumescent flame retardant on the thermal and mechanical properties of plasticised PLA, Plastics, Rubber and Composites, 50:3, 127-136

P. Somdee, A. Hasook, (2017), Effect of modified eggshell powder on physical properties of poly(lactic acid) and natural rubber composites, Materials Today: Proceedings, Volume 4, Issue 5, Part 2, 2017, Pages 6502-6511.

Amirouche Bouamer, Nasser Benrekaa, Abderrahmane Younes, (2021), Characterization of polylactic acid ceramic composites synthesized by casting method, Materials Today: Proceedings, Volume 42, Part 5, Pages 2959-2962.

Krithiga, Gunasekaran \& Sastry, Thotapalli. (2011), Preparation and characterization of a novel bone graft composite containing bone ash and egg shell powder. Bull. Mater. Sci. Indian Academy of Sciences. 34. 177-181.
Valeriya L. Kudryavtseva, Li Zhao, Sergei I. Tverdokhlebov, Gleb B. Sukhorukov, (2017), Fabrication of PLA/CaCO3 hybrid micro-particles as carriers for water-soluble bioactive molecules, Colloids and Surfaces B: Biointerfaces, Volume 157, Pages 481-489 